\title{
KEY TO GOOD FIT: BODY MEASUREMENT PROB- LEMS SPECIFIC TO KEY DIMENSIONS
}

\author{
Mariette Strydom and Helena M de Klerk
}

\section{OPSOMMING}

Die doel met hierdie navorsing (as deel van 'n groter studie) was om die probleme wat die Suid-Afrikaanse Klerebedryf met die sleutel liggaamsmates vir die vervaardiging van klere ondervind, te verken en beskryf. Suid-Afrika kon nie in die laaste aantal jare daarin slaag om die uitvoer van klereprodukte te verhoog nie, maar het egter die uitdaging om uitvoere te verhoog, aanvaar. Een manier om hierdie uitdaging die hoof te bied, is om met goeie pas ' $n$ meer mededingende kledingproduk vir die plaaslike sowel as internasionale mark te verseker. Die sleutelmates is die eerste stap in die proses om ' $n$ goedpassende kledingstuk daar te stel. Om konsekwentheid met groottes te verseker is dit noodsaaklik dat die sleutelmates op ' $n$ gestandaardiseerde manier deur alle vervaardigers en kleinhandelaars gemeet word. Aangesien sleutelmates ' $n$ integrale deel van die kledingstuk vorm, sal die effektiewe kommunikasie van toepaslike sleutelmates en klere-groottes aan die verbruiker die keuse van korrekte grootte kledingstukke aansienlik vergemaklik.

'n Pos-opname is gedurende Julie tot November 2002 gedoen, deur vraelyste na Suid-Afrikaanse klere- en skoenvervaardigers en kleinhandelaars te stuur. Uit die terugvoer op die pos-opname is ' $n$ aantal respondente vir individuele onderhoude met behulp van doelbewuste steekproefneming gekies. 'n Gestruktureerde onderhoudskedule het verseker dat akkurate beskrywings van liggaamsmates tydens die onderhoude in Julie 2003 verkry is. Data wat tydens die pos-opname ingesamel is, is deur middel van frekwensie tabelle ontleed om ' $n$ lys van liggaamsmates, wat deur die respondente gebruik word, saam te stel. Transkripsies van die onderhoude is deur inhoudsanalise ontleed, en sodoende is sleutelmates geïdentifiseer en gedefinieer. Hierdie sleutelmates is daarna vergelyk met die sleutelmates wat in 'n studie deur Simmons en Istook (2003) geïdentifiseer is.

Die resultate weerspieël dat, alhoewel internasionale beskrywings vir $100 \%$ van die sleutelmates beskikbaar is, daar nogtans probleme met landmerke ondervind word, en dat daar min konsensus rakende die metingsmetode en identifisering van landmerke is. ' $n$ Studie deur Hwang en Istook (2001) het ook bevind dat daar ' $n$ gebrek aan konsensus ten opsigte van terminologie en beskrywings van liggaamsmates is. Die onsekerheid in die industrie ten opsigte van waar en hoe die sleutelmates geneem moet word, is te verstane as in ag geneem word dat Suid-Afrikaanse kleinhandelaars en vervaardigers van standaard internasionale beskrywings afhanklik is. Hierdie onsekerheid word weerspieël deurdat daar vir slegs $41,2 \%$ van die beskrywings van sleutelmates konsensus is ten opsigte van hoe die sleutelmates geneem moet word. Dit is van uiterste belang dat die beskrywings van liggaamsmates absoluut korrek en herhaalbaar is, sodat dit op die mees akkurate manier in produksie aktiwiteite toegepas kan word.

Samevattend en ter aanbeveling is dit duidelik dat die klere-industrie die identifisering van landmerke, asook spesifieke metodes vir die neem van die mates op die liggaam, moet aanspreek. Landmerke is krities wanneer liggaamsmates na die patroon oorgedra word. Dit is tot voordeel van alle lande wat klere vervaardig om ooreen te stem ten opsigte van watter landmerke gebruik moet word. Dit is ook noodsaaklik dat rolspelers in die industrie in detail beskryf hoe hierdie landmerke konsekwent geïdentifiseer kan word en presies hoe die sleutel liggaamsmates geneem behoort te word. Die pas van ' $n$ kledingstuk is ' $n$ baie belangrike aanduiding van die kwaliteit daarvan. Uitnemende kwaliteit is die enigste manier om mededingend te bly in ' $n$ uiters kompeterende bedryf, en deur akkurate sleutelmates wat uiteindelik goeie pas verseker, kan die uitdaging om nasionaal en internasionaal mededingend te wees, aangespreek word.

- Ms M Strydom *

Department of Consumer Science

E-mail: mariette.strydom@up.ac.za

Tel: +27 (0)12420 4310

Fax: +27 (0)12420 2855

${ }^{*}$ Corresponding author

- Prof HM de Klerk

Department of Consumer Science

University of Pretoria 


\section{BACKGROUND}

The goal of providing custom-fitted quality apparel to "every body" has not been achieved even into the $21^{\text {st }}$ century (Bye et al, 2006). The garment production and retail industries have struggled with the challenge of providing well-fitting garments for the variety of the population since the industrial revolution and the first introduction of mass-produced clothing (Ashdown, 2007:xvii; Bye et al, 2006; Knight, 1994:1). Because people vary along many dimensions, a multitude of sizes, proportions and postures need to be accommodated (Ashdown, 2007:xvii). As is the case in many developed and developing countries, one of the challenges that the South African apparel industry still faces, is that of providing well-fitting garments for the variety of human shapes and sizes. According to Shim and Istook (2007), LePechoux and Ghosh (2002) and Roberts (1972:12,13), different ethnic groups have different body proportions and shapes, and therefore apparel fit problems are likely to be aggravated by the diversity of figure shapes (Ashdown \& Dunne, 2006; Bougourd, 2007:124 ; Zwane \& Magagula, 2007), as can be found among the different ethnic groups in South Africa. The black affluent group of middle class South Africans has grown in numbers from 2-million in 2005 to 3-million in 2010 and their collective spending power has risen from R103-billion to R237-billion in 2010 (Da Silva, 2010; CNBC Business, 2010; Simpson \& Dore, 2007:4). According to Simpson and Dore (2007:7) an increase in income leads to a shift in social class which could indicate a shift in consumption patterns and lifestyle changes, and this is evident in the black middle class' emphasis on luxury and branded goods, especially clothing (Odhiambo, 2008; CNBC Business, 2010).

It is common knowledge that in some cultures, mainly in Africa, the bottom-heavy body shape typifies a substantial percentage of black African women (Zwane \& Magagula, 2007). In an effort to create loyal customers, retailers pride themselves on a unique fit through private labels, which represent the body image and profile of their target market (Bye \& LaBat, 2005; Myers-McDervitt, 2009:5). Retailers and manufacturers expect the human body to match the clothing standard for their target market, based on the ideal or hourglass figure (Bye et al, 2006). Therefore, dissatisfaction with fit is still one of the major complaints expressed by female apparel consumers (Loker et al, 2005), and according to Petrova (2007:59) this leads to loss of customers because fit is an important criterium in a consumer's evaluation of an apparel product (Bye \& LaBat, 2005; Newcomb \& Istook, 2004; Shim \& Istook, 2007). Understanding how body shapes differ from the ideal figure is crucial, because to achieve customer loyalty good fit is imperative. Providing more consumers with better fit will benefit the retailer, the manufacturer, as well as the consumer (Zwane, et al, 2010).

The development of three-dimensional body scanners has opened up new possibilities for the measurement and analysis of the human body (Ashdown, 2002; Connell et al, 2006; Zwane et al, 2010). Unfortunately three-dimensional body scanners are, especially in developing countries, not always available for use in the apparel industry. In general, measurements are therefore taken in the traditional tailor's manner with normal tape measures. In order to ensure well-fitting garments and good fit in general, it is, however, of the utmost importance that manufacturers and retailers should have a sound knowledge on exactly how and where on the body the various measurements should be taken, and use the equipment that will enable them to consistently take accurate measurements. According to Bye et al (2006) developing accurate and reliable methods of measuring the body, is one part of solving the fit puzzle. Unfortunately, very little is known about how apparel industries ensure good fit, especially with regard to the taking of key body measurements. The purpose of this research (as part of a broader research project) was therefore to explore and describe the problems that the South African Clothing Industry currently experiences with regard to the key body measurements needed for the manufacturing of well-fitting clothes.

\section{LITERATURE REVIEW}

The basis for designing well-fitting garments for a local or international target market is reliable anthropometric data. Scientific garment cutting is based on measurements of the human form, and therefore the correct set of key dimensions related to the specific product is vitally important. Key dimensions are measurements that serve as predictors of the sizes of other parts of the body (Chun-Yoon \& Jasper, 1996). A key dimension is a body dimension that has a strong relationship with most other body dimensions that are important in the design of the garment. According to Winks (1990:22), the correlations among relevant body measurements are critical in the manufacturing of body-fitting garments. Key dimensions are fundamental to the definition of body size and are used to assign an appropriately sized garment for a wearer (Winks, 1997:24; Apeagyei \& Otieno, 2007). It is therefore critical for fit that a producer is exactly sure how and where these key dimensions should be measured on the human body. For consistency in sizing, it is also important that the key dimensions be measured in a standardised way by all manufacturers and retailers. Various aspects can determine which key dimensions are required to manufacture certain garments, for example, who the garment is made for and which part of the body is to be covered. Tamburrino (1992) explains, for example, that a tailored jacket may require at least six dimensions for construction, namely chest or bust girth, waist girth, seat girth, jacket length, sleeve length and waist length, while a men's dress shirt requires three dimensions neck girth, shoulder girth and sleeve length. These key measurements are the first steps towards drafting a correct pattern (Joseph-Armstrong, 2010:38). Fit is determined by pattern making (Hudson, 1980), and pattern making starts with the key body measurements (Joseph-Armstrong, 2010:38). The way in which the human body is measured is critical to the development of an apparel pattern, as key body measurements that have been measured incorrectly, 
can lead to inaccurate patterns and ill-fitting garments (Bye et al, 2006).

Key dimensions are used as the basis for creating sizing systems, drafting garment patterns, grading patterns, choosing fit models for fit testing and for communicating size designation of garments to the consumer. Key dimensions are therefore fundamental to the definition of body size and are used to assign an appropriately sized garment to a wearer (Winks, 1997:24; Apeagyei \& Otieno, 2007). It is therefore critical for fit that one is exactly sure how and where these key dimensions should be measured on the human body. For consistency in sizing it is also important that the key dimensions be measured in a standardised way by all manufacturers and retailers (Bye et al, 2006).

A sizing system generates the size charts, which provide the measurements necessary for garment production (Kunick, 1984:9). Chun-Yoon and Jasper (1993) and Ashdown and Dunne (2006) identified the problems with fit as being the result of sizing systems that are based on outdated anthropometric data, and sizing systems' lack of appropriate sizes to accommodate the full range of variation in body types occurring in the current population. Very few sizing systems accommodate differences in body proportions related to age, ethnicity or body weight (Giddings \& Boles, 1990; Goldsberry et al, 1996; Ashdown \& Dunne, 2006) because it is the function of a sizing system to establish limits regarding the variability in sizes. To perform this function a sizing system prescribes the set of key dimensions relevant to each specific size. However, an adapted version of the British sizing system is used in South Africa and thus the block patterns and garments are not made from body measurments of the South African population, explaining the problem of ill-fitting and unsatisfactory clothing (Zwane \& Magagula, 2007). But if new sizing systems are to be developed, not only should the body measurements be reviewed but also the definitions of the body measurements, including key dimensions (Honey and Olds, 2007).

The key dimensions prescribed by the sizing system are firstly used in the drafting of the block patterns for the specific garment size. If the pattern maker starts off with inaccurate body measurements, no matter how accurate all the other aspects of the production of a garment up to labelling and fit and wear testing are executed, it will be almost impossible to create a good fit. According to Myers-McDevitt (2009:241) a perfectfitting garment begins with accurate measurements. Hudson (1980) confirms that fit is determined by pattern making. During pattern making, key body measurements are used together with specific amounts for ease of movement and design ease (Zwane et al, 2010), to create a specific silhouette or style of garment. Therefore, for a garment to meet the needs and desires of the consumer, the key dimensions together with the correct amounts of ease must be translated into garment measurements, appropriate for the garment design and fabric variables (Bye et al, 2006). It is therefore not possible to create suitable garment measurements without an applicable set of body measurements as a starting point.

Secondly, key dimensions are important for fit tests. Before a pattern goes into production, a sample garment is made and then evaluated in terms of fit, to ensure that it meets the requirements of the company. Le Pechoux and Ghosh (2002), Yu (2004:33-35), Bye and LaBat (2005) and Joseph-Armstrong (2010:2324) state that a live model or a dress form (dummy) can be used to verify whether a garment fits the measurement specifications. The choice of a live model and/or an appropriate dummy is based on the key dimensions prescribed by the sizing system for the sample size of the garment (Le Pechoux \& Ghosh, 2002). Fit testing is critical to reveal problems with the fit or the functionality of a garment, and can result in a better product. Improving garment fit before mass production is undertaken, is necessary to ensure garment quality and consumer satisfaction, and to avoid unnecessary expenses due to the production of unsuitable garments. Fit testing and wear testing are the means to improve garment fit before mass production, provided that the key dimensions used for garment design and for choosing the fit model are accurate.

The size label is a way to communicate sizing information to the consumer. The size label should assist the consumer in selecting the appropriate size garment. The size code used on the label can however be a code or number that does not refer to body or garment measurements at all (Chun, 2007:220). A labelling system should enable consumers to find their correct garment sizes easily without trying on too many garments. Consumers do indeed use size labels to find the garment size before they actually try on a garment (Chun-Yoon \& Jasper, 1993). Brown (in Chun-Yoon \& Jasper, 1993) as well as Honey and Olds (2007), indicate that retailers and manufacturers use the size label as a marketing tool. The result of this is clothing from separate companies differing so much that garments indicating the same size on the label, do not nearly have the same dimensions. Sizing systems are also often created and adjusted by trial and error, resulting in changes to dimensions without changing the size designation (Chun, 2007:222). This miscommunication between clothing industry and the consumer leaves the customer confused and dissatisfied with his or her clothing shopping experience, but may also induce negative feelings towards one's own body (LaBat \& DeLong, 1990). Clear size labelling, which provides the key dimensions that a specific size is supposed to fit, will reduce manufacturers' and retailers' costs on account of frequent returns and damage to garments caused by customers frequently trying them on (Chun-Yoon \& Jasper, 1993). It will also simplify garment selection for the consumer. Effective communication of the relevant key dimensions, together with size codes, is therefore essential for the consumer and for the clothing industry.

The interaction and interdependence between key dimensions and sizing systems, block patterns, grading, fit testing and size communication are 
TABLE 1: BREAKDOWN OF THE SAMPLE

\begin{tabular}{|l|c|c|c|c|c|}
\hline \multicolumn{1}{|c|}{ Categories of respondents } & $\begin{array}{c}\text { Questionnaires } \\
\text { sent }\end{array}$ & $\begin{array}{c}\text { Questionnaires } \\
\text { rejected }\end{array}$ & $\begin{array}{c}\text { Questionnaires final } \\
\text { total }\end{array}$ & $\begin{array}{c}\text { Questionnaires } \\
\text { returned }\end{array}$ & $\begin{array}{c}\text { Respondents } \\
\text { interviewed }\end{array}$ \\
\hline Clothing manufacturers & 264 & 88 & 176 & 30 & 7 \\
\hline Footwear manufaturers & 196 & 70 & 99 & 14 & 1 \\
\hline Headwear manufacturers & 21 & 5 & 16 & 4 & \\
\hline Retailers & 15 & 0 & 15 & 5 & 3 \\
\hline Lasts / Fit dummy manufacturers & 3 & 0 & 3 & 1 & 1 \\
\hline Total & $\mathbf{4 7}$ & $\mathbf{1 6 3}$ & $\mathbf{3 0 9}$ & $\mathbf{5 4}$ & $\mathbf{1 2}$ \\
\hline
\end{tabular}

abundantly clear. It is therefore important that the key dimensions be current, accurate, well-defined and representative of the population for which the sizing system is being developed. If population measurements, and consequently the key dimensions, are outdated and inaccurate for a specific population, the best sizing system will not be able to ensure wellfitting garments for that population. Since little is known about how apparel industries function with regard to the taking of key body measurements, or the problems that they experience with regard to these measurements, the specific research aims of this study were:

- to compare international descriptions of identified key dimensions with the South African respondents' descriptions of the identified key dimensions; and

- to describe the problems that the South African apparel industry is experiencing with key dimensions.

\section{METHODOLOGY}

To address the research problem new or primary data was collected and existing or secondary data was analysed. A quantitative research paradigm was necessary for this study, and quantitative data collection techniques were used to adequately address the research problem and objectives. A postal survey was conducted among South African apparel and footwear manufacturers and retailers, from which a number of respondents were selected for follow-up individual interviews. In this manner, key dimensions were identified and defined.

\section{Sampling}

South African apparel and footwear manufacturers and retailers were the target population for this study. The Clothing Federation of South Africa Handbook (2000/1) and Shoes and Views Directory (2001) were used to define the sampling frame. The major retail chains were included in the target population. According to Frings (1999:362), chain stores are a group of stores that sell essentially the same merchandise and are centrally owned, operated and merchandised. It is assumed that the major retailers lead the way as far as sizing systems used are concerned, and therefore have more experience and knowledge with regard to body measurements and key dimensions. Dunne (2000) supports the view that smaller retailers follow the lead of the major retailers, and therefore, only national retailers of both clothing and footwear products were included. Manufacturers for the footwear industry, and figure form manufacturers for the cloth- ing industry, are also important users of body measurements and formed part of the target population for this study.

Based on the fact that the response rate for postal surveys is often poor (Neuman, 2000:266), it was decided to include the entire target population of 472 manufacturers and retailers in the survey. One hundred and sixty three respondents were rejected because of factories that had closed down, respondents that were not manufacturers but only distributors or importers, and respondents that were untraceable. The new total of 309 manufacturers and retailers were thus used as the final total of questionnaires in the study. A purposive or judgemental sample was taken from the 54 manufacturers and retailers that responded to the postal survey. The 12 companies selected to be interviewed were selected by keeping the purposes of the study in mind, and based on the parameters listed below. A breakdown of respondents included in the sample is illustrated in table 1 . This sampling technique ensured a representative sample for the interviews. The interview sample was selected according to the following parameters:

geographical area;

- manufacturers and retailers covering the whole spectrum of garment categories;

- manufacturers and retailers catering for specific figure requirements;

- manufacturers and retailers that indicated problems with specific measurements;

- involvement in the development of sizing systems; and

- number of years in business.

\section{Data collection methods}

The closed-question questionnaire seemed appropriate for the postal survey, because the objective was to identify all the body measurements that are used by the clothing industry. Time is critical in the clothing and footwear industries, and closed questions are easier and quicker for respondents to answer (Neuman, 2000:261).

Because the survey was followed by an interview, the researcher kept a complete and accurate record of questionnaires posted and returned. The survey was not anonymous but confidentiality was guaranteed. Some strategies to achieve a better response rate included phone calls to follow up non-responses, and sending a second questionnaire by e-mail or by post. 
The response rate was poor (17,5\%); however, it was better than the $10 \%$ response rate generally expected from a postal survey.

The questionnaire was developed by identifying measurements as contained in local and international documentation, such as published by the International Standards Organisation (ISO), the American Society for Testing and Materials (ASTM), and documents of the South African Bureau of Standards (SABS) (refer to Strydom, 2006:38-39 for the full list). Body dimensions that were included in the Nedscan (2001) (Dutch part of the CEASAR project) and SizeUK (2000) anthropometric surveys, were also considered for inclusion in the questionnaire. The questionnaire was reviewed by an expert in the clothing industry, and following his recommendation, figures indicating the positions of the body dimensions were included to enhance the clarity of the questionnaire. The questionnaire is available in Strydom (2006:276-324).

Individual interviews, using a structured interview schedule, seemed the appropriate technique to gather accurate definitions of the identified measurements. This ensured that the objectives of the study were covered during the interview. Four production managers, one quality assurance manager, five fit technologists and two designers/pattern makers from the apparel industry were interviewed (total 12). This contributed to the reliability of the data.

Years of experience in the industry, rather than theoretical knowledge of the definitions of the measurements, often contributed to respondents' finding it difficult to describe or explain how and where measurements are taken. The interview technique enabled the researcher to observe how and where a specific measurement is taken, because it provided the respondent the opportunity to demonstrate how measurements were actually taken, rather than to provide mere descriptions. Audiotapes were kept and notes were taken where possible during the interview, in order to preserve the original data and to confirm the credibility of the data.

\section{Data analysis}

The data obtained from the postal survey made it possible to compile a list of all the key body measurements used by the survey's respondents. Frequency tables seemed sufficient for this stage of the research and gave a complete overview of collected data. It also assisted in the identification of respondents who have been in business for a longer period of time, and who are involved in the development of sizing systems and provide for special figure requirements. These aspects were important considerations in the sampling for the interviews.

Content analysis was applied to analyse the transcriptions of the interviews, together with notes taken during the interviews and documents received from some of the respondents, for example measurement charts and illustrations. A quantitative analysis was then done on a spreadsheet, to identify and define key dimensions and the problems experienced with them. The key dimensions used by the respondents were also compared to the key dimensions identified from pattern-making textbooks and patternmakers, in a study by Simmons and Istook (2003).

\section{RESULTS AND DISCUSSION}

Key dimensions are the suggested body measurements that can be used to describe the size of a garment (Chun-Yoon \& Jasper, 1993). The ISO suggests that key dimensions be indicated on the size labels, but this is not the case in South Africa. The respondents were asked to name the critical measurements for pattern making and thus for ensuring a good fit.

The measurements identified as key dimensions were compared to the 16 critical measurements identified in a study by Simmons and Istook (2003), and then the

TABLE 2: $\quad$ KEY DIMENSIONS IDENTIFIED ( $\mathrm{N}=12)$

\begin{tabular}{|c|c|c|}
\hline $\begin{array}{l}\text { Key dimensions identified in the study by Simmons \& Istook } \\
\qquad(2003)\end{array}$ & Key dimensions identified by respondents & Number of respondents \\
\hline 1. Mid-neck/neck base & Neck girth & 5 \\
\hline 2. Chest / bust & Bust / Chest & 9 \\
\hline 3. Waist by natural indentation / waist by navel & Waist girth & 8 \\
\hline 4. Hips / seat & Hip girth & 7 \\
\hline 5. Sleeve length / arm length & Over-arm / sleeve length & 4 \\
\hline 6. In-seam & Inside leg length & 8 \\
\hline 7. $\quad$ Out-seam & Outside leg length & 9 \\
\hline 8. Shoulder length & & 0 \\
\hline 9. Across back & Across back width & 3 \\
\hline 10. Across chest & Across front width & 2 \\
\hline 11. Back of neck to waist & Back waist length (cervical to waist) & 1 \\
\hline 12. Rise & Body rise / Crotch depth & 1 \\
\hline 13. Crotch length & Total crotch length & 6 \\
\hline 14. Thigh circumference or girth & Thigh girth & 4 \\
\hline 15. Biceps circumference or girth & Biceps girth & 4 \\
\hline 16. Wrist circumference or girth & Wrist girth & 2 \\
\hline
\end{tabular}


descriptions of the key dimensions were compared as to the following aspects:

- whether an international description was available;

- whether there was consensus among the international descriptions, or only one international description;

- whether there was consensus among the respondents' descriptions, only one description, or no description from respondents;

- whether there was consensus between the international and the respondents' descriptions;

- whether problems were related to no consensus about measuring straight or on the contour;

- whether problems were related to landmarking;

- whether problems were related to landmarking as well as to no consensus.

Sixteen measurements that were considered critical in the design of the initial blocks or slopers, needed for well-fitting garments, were identified in a study by Simmons and Istook (2003). Simmons and Istook (2003) consulted pattern-making experts and textbooks to determine these 16 critical measurements. In Table 2 the 16 critical measurements are listed and compared to the measurements that the respondents in this study identified as key dimensions. For the purposes of this article only measurements relevant to garments were included, and not key dimensions for headwear or footwear.

Key dimensions should form an integral part of the garment (McConville in Chun-Yoon \& Jasper, 1996). The critical measurements identified by Simmons and Istook (2003) that would be applicable to trousers, included waist by natural indentation/waist by navel circumference, hips/seat circumference, in-seam, outseam, rise, crotch length and thigh circumference. The key dimensions stated by the respondents from this study correspond with the critical measurements identified in the study by Simmons and Istook (2003). It is important to note that the respondents referred to the circumference at the natural waist and not at the level of the navel, which is suggested as an alternative measurement by Simmons and Istook (2003). It is alarming that rise was identified as a key dimension by one respondent only. Rise is very important in order to distribute the crotch length and subsequently determine the curve of the crotch seam. The correct shape of the crotch seam is critical for the fit of trousers, and it is therefore surprising that the rise measurement was not regarded as a key dimension by more respondents.

With regard to skirts, waist and hip girth are the only key measurements among the 16 critical measurements identified by Simmons and Istook (2003) that are necessary for drafting a skirt pattern. In addition to waist and hip measurements, the South African respondents identified garment front length and garment back length as key dimensions for skirts. Hip circumference, waist circumference and garment length (outer leg length for trousers) are the most used measurements for skirts and trousers, as suggested by Chun-Yoon and Jasper (1993), and this is con- firmed by the results of this study.

The critical measurements from the study by Simmons and Istook (2003) that would be applicable to upper body garments included mid-neck/neck base circumference, chest/bust circumference, waist by natural indentation/waist by navel circumference, hips/ seat circumference, sleeve length/arm length, shoulder length, across-back, across-chest, back of neck to waist, biceps circumference, and wrist circumference. These measurements were also identified as key dimensions by the respondents from this study, except for shoulder length, which refers to the distance from side neck to the shoulder joint (Simmons \& Istook, 2003). A study by Chun-Yoon and Jasper (1996), as well as Joseph-Armstrong (2010:35, 40), identify shoulder length as a key dimension for ladies' upper body garments. The respondents noted that shoulder to shoulder is a key dimension; however, in the above-mentioned two studies, this measurement was not listed. Shoulder to shoulder could be critical for men's wear to aid in determining the corresponding garment measurement. This would be applicable to men's shirts and t-shirts that are not really closefitting. For ladies, the appearance of the garment at the shoulder can determine the success of the garment, particularly in tailored jackets. If the shoulder seams do not fit properly the garment can appear to be too small or too large, regardless of whether the bust dimension is correct. Therefore the shoulder length, from side neck to shoulder, should be a critical measurement. In addition, the respondents identified centre back garment length as a key dimension. Although only one respondent identified nape to waist as a key dimension, the centre back garment length would incorporate the nape to waist dimension. Garment length was also listed as a key dimension for ladies' upper body garments by Chun-Yoon and Jasper (1993).

The use of key dimensions on a national level compares well with key dimensions used internationally. What was surprising was that nape to waist, which is a critical measurement for upper body garments, namely to position the waistline correctly, and rise height, which is critical for the fit of trousers, were both identified by only one respondent. Shoulder length, also critical for the fit of upper body garments, was not identified as a key dimension by any of the respondents. The reason for this could be that the respondents question the accuracy of measurements concerning side neck point as a landmark, because of the difficulty to consistently identify the exact position of the landmark.

Table 3 reflects the results from the comparison of the descriptions of the key dimensions as identified by Simmons and Istook (2003), as well as those identified by the respondents (although the broader research project included all measurements that the South African Clothing Industry identified for apparel manufacturing). These 16 key dimensions are reflected as 17 key dimensions in Table 3 because bust (for ladies wear) and chest (for menswear), and sleeve length (menswear) and arm length (ladies 
TABLE 2: COMPARISON OF DESCRIPTIONS OF KEY DIMENSIONS

\begin{tabular}{|c|c|c|c|c|c|c|c|c|}
\hline Key dimension & $\begin{array}{l}\text { International } \\
\text { description }\end{array}$ & $\begin{array}{l}\text { International } \\
\text { consensus }\end{array}$ & $\begin{array}{l}\text { Consensus } \\
\text { among } \\
\text { respondents }\end{array}$ & $\begin{array}{l}\text { Consensus } \\
\text { between } \\
\text { international and } \\
\text { respondents' } \\
\text { descriptions }\end{array}$ & Problems & $\begin{array}{l}\text { Problems } \\
\text { related to } \\
\text { straight / } \\
\text { contoured }\end{array}$ & $\begin{array}{l}\text { Problems } \\
\text { related to } \\
\text { landmarking }\end{array}$ & $\begin{array}{l}\text { Landmarking } \\
\text { difficulties } \\
\text { and no } \\
\text { consensus }\end{array}$ \\
\hline Neck base girth & Yes & Yes & No & No & Yes & No & Yes & Yes \\
\hline${ }^{*}$ Chest girth & Yes & Yes & Yes & Yes & No & No & Yes & No \\
\hline${ }^{*}$ Bust girth & Yes & Yes & No & No & No & No & Yes & Yes \\
\hline${ }^{*}$ Waist girth & Yes & Yes & Yes & Yes & No & No & Yes & No \\
\hline *Hip girth & Yes & Yes & No & No & No & No & Yes & Yes \\
\hline Shoulder to wrist & Yes & One description & No & No & Yes & No & Yes & Yes \\
\hline Arm length bent & Yes & Yes & No & No & Yes & No & Yes & Yes \\
\hline Inside leg length & Yes & Yes & Yes & Yes & Yes & No & Yes & No \\
\hline Outside leg length & Yes & Yes & No & No & Yes & Yes & Yes & Yes \\
\hline Across back width & Yes & No & No & No & Yes & No & Yes & Yes \\
\hline Across front width & Yes & No & No & No & Yes & No & Yes & Yes \\
\hline${ }^{*}$ Back waist length & Yes & Yes & Yes & Yes & No & Yes & Yes & No \\
\hline Body rise & Yes & No & No & No & Yes & No & Yes & Yes \\
\hline Total crotch length & Yes & Yes & Yes & Yes & Yes & No & No & No \\
\hline${ }^{*}$ Thigh girth & Yes & No & No & No & No & No & Yes & Yes \\
\hline Biceps girth (straight) & Yes & Yes & Yes & Yes & No & No & No & No \\
\hline Wrist girth & Yes & Yes & Yes & Yes & No & No & No & No \\
\hline Totals - Yes & 17 & 12 & 7 & 7 & 9 & 2 & 14 & 10 \\
\hline$\%$ Yes & 100.0 & 70.6 & 41.2 & 41.2 & 52.9 & 11.8 & 82.4 & 58.8 \\
\hline Totals - N/A & 0 & 1 & 0 & 0 & 0 & 0 & 0 & 0 \\
\hline$\%$ N/A & 0.0 & 5.9 & 0.0 & 0.0 & 0.0 & 0.0 & 0.0 & 0.0 \\
\hline Totals - No & 0 & 4 & 10 & 10 & 8 & 15 & 3 & 7 \\
\hline$\%$ No & 0.0 & 23.5 & 58.8 & 58.8 & 47.1 & 88.2 & 17.6 & 41.2 \\
\hline Total & 17 & 17 & 17 & 17 & 17 & 17 & 17 & 17 \\
\hline
\end{tabular}

wear) are counted as one dimension in the study by Simmons and Istook (2003), but as two separate dimensions for the purpose of this study. In addition, the South African respondents did not identify shoulder length as a key dimension. Table 3 also reflects the existence of international consensus, national consensus, as well as international-national consensus with regard to how the key dimensions should be taken. In cases where only one description or no description was available, it was classified as no conclusion possible. The percentage of cases where problems with regard to the taking of the key dimensions were reported, and whether these problems were related to the measurements being taken on the contours of the body or in a straight line next to the body, whether problems were related to landmarking, or whether to landmarking together with a lack of consensus on the measurement definition, are also indicated in the table.

International descriptions are available for all (100\%) of the key dimensions, and there is consensus among the international descriptions for $70,6 \%$ of the key dimensions. For $29,4 \%(23,5 \%+5.9 \%)$ of the key measurements there either is no international consensus or no conclusion was possible regarding consensus because only one description was available. For more than half $(58,8 \%)$ of the key dimensions, the respondents did not agree on the description of how and/or where the measurement should be taken. These are also the same key dimensions where the respondents disagreed with the international descriptions. This could be an indication that the international descriptions may be vague with regard to landmarking and measuring method, which leads to confusion and a different interpretation of the description by the respondents. Because of the importance of the key dimensions, this finding is real cause for concern and needs serious attention from the industry, since these measurements are critical for providing a good fit in garments. This has definite implications for the taking of consistent and accurate measurements, which further impacts on the drafting of well-fitting patterns.

From Table 3 it is clear that the respondents experienced problems with $52,9 \%$ of the key dimensions. This can only predict problems with the sizing and fit of clothing items. The industry realises the problem by admitting to having problems with the key dimensions. It implies that the respondents from the industry probably value and are interested in having accurate body measurements, which highlights the need for a body measurement survey of the South African population. The problems with the key dimensions are related to landmarking per se $(82,4 \%)$, as well as to landmarking and lack of consensus as to where the measurement should be taken $(58,8 \%)$. This has important implications for taking accurate body measurements and drafting well-fitting patterns, especially because the key dimensions form the foundation of the basic patterns. Once again, the importance of having detailed descriptions on the identification of 
landmarks and measuring techniques is highlighted. Since the key dimensions are so important for the proper fit and correct sizing of garments, the situation regarding the descriptions of key dimensions needs serious attention from the clothing industry.

The results indicate that the highest percentage of problem measurements was experienced with the taking of width and depth measurements. To be able to take the width and depth measurements consistently and accurately, special equipment is needed which the respondents did not have. This lack of equipment could possibly be the reason for the large number of problems experienced with the width and depth measurements. For the sake of consistency and accuracy of measurements, one would also expect a higher rate of consensus among respondents' descriptions of measurements, and between the international and the respondents' descriptions.

The interviews revealed that the problems that the respondents experienced with regard to all measurements, and/or the fact that there was no consensus between the respondents' and the international descriptions, were due to one or more of the following factors:

- It was a difficult measurement to take (as in the case of crotch length, for instance);

- The international description was not clear with regard to the landmarking - exactly where and how the landmark should be determined (as in the case of armscye depth, for instance);

- Uncertainty with regard to whether the measurement should be taken on the contour of the body or in a straight line (as in the case of cervical height, for instance);

- The unavailability of the necessary anthropometric tools (as in the case of neck width, for instance).

The above results confirm Hwang and Istook's (2001) study, which found that a lack of consensus exists regarding terminology, and that traditional body measurement methods for apparel have mostly been based on "feel" by hand. Therefore, a definite need seems to exist for as much information as possible on the body measurements of South African consumers. It is also of vital importance to potential industry users that measurement definitions be absolute and repeatable, so that they can be used most accurately for customisation and production. This is in accordance with the view held by Simmons \& Istook (2003).

It was also clear from the interviews that much effort goes into fit testing, and live models as well as dummies are used. The respondents also put effort into developing the perfect dummy. It is commendable to use both methods for fit testing because the dummy is the control for the garment specifications. Fit testing is done before mass-production starts, which is a good practice, since any fit problems can be corrected before the garment reaches the consumer (Smit, 1997; Le Pechoux \& Ghosh, 2002). It also prevents wastage due to garments being manufactured to the wrong size specifications. Choice of a live model and/or an appropriate dummy is, however, based on key dimensions prescribed by the sizing system for the sample size of the garment. Fit testing and wear testing are therefore only the means to improve garment fit before mass production, provided that the key dimensions used for garment design and for choosing the fit model, were correct.

\section{CONCLUSION AND IMPLICATIONS}

The overall conclusion that can be drawn with regard to key dimensions is that, although international descriptions are available for $100 \%$ of the key measurements, major problems seem to be experienced with landmarking, and with consensus about the measuring method as well as the landmarking. Landmarks are crucially relevant when transferring measurements to a pattern and play a defining role in the accuracy of pattern drafting. The goal of measuring methods is to provide a description of the body that will aid in the development of a garment that fits an intended body (Bye, et al, 2006). In order to translate a body measurement to a garment pattern, there is a need to identify consistent body landmarks that directly relate the body to the pattern (Bye, et al, 2006; Connell, et al, 2006; Joseph-Armstrong, 2010: 30).

If one assumes that South African retailers and manufacturers probably rely on standardised international descriptions, one can understand the confusion in the industry as to where and how the key dimensions should be taken. This is reflected in only $41,2 \%$ of cases with consensus among respondents as to how the measurements should be taken, as well as consensus between respondents' descriptions and international descriptions for, again, less than half of the measurements $(41,2 \%)$. One would expect, and in fact require, a much higher rate of consensus in order to ensure consistency and accuracy of measurements. Since these are the key dimensions, it will require serious attention from the industry. The key dimensions have serious implications for the sizing as well as the fit of garments. They determine the size and measurements of the final garments because they are used for the drafting and grading of patterns. The sample garment is fit-tested on a dress form and/ or a live model whose measurements are based on the key dimensions. In some cases the key dimensions are also indicated on the label together with the size designation to assist the consumer in finding the correct garment size. Key dimensions play a vital role in the complete garment production process, and the problems experienced can therefore not be ignored.

Since landmarking seems to be the biggest contributor to the problems experienced with key dimensions $(82,4 \%)$, it is critical for accuracy and comparability that the data be collected using consistent measuring methods and landmark identification, which would most probably only be possible when 3-D body scanners are used. Landmark identification can be more difficult with some figures than others, for instance, landmarking the waist may be easier with a hourglass figure than a rectangular figure (Connell et al, 2006). The 3-D body scanner identifies landmarks automati- 
cally and consistently, and such a survey could assist the industry in reaching consensus with regard to landmarking and the exact measuring positions on the body.

Because of the fact that the labour intensity of apparel production can generate a substantial number of jobs, apparel manufacturing is still well suited to those nations seeking economic development. However, in order to survive in a highly competitive market, manufacturers and retailers have to focus on both price and non-price factors, such as quality, innovation and adherence to standards. As a result of more competition in the apparel manufacturing and retail sectors, and to be competitive with Eastern markets, it is therefore important for retailers and manufacturers to improve fit, because fit is an important indicator of quality and better quality is the only way (especially in vulnerable and the so-called loser countries) to face the challenge to stay nationally and internationally competitive.

The importance of accurate and current body measurements can therefore no longer be ignored by apparel manufacturers and retailers. It is necessary that the South African industry addresses the problem of consensus with regard to landmarking and measuring methods. Even if the problem is not addressed on an international level, it is to the advantage of every apparel manufacturing country that they reach consensus on which landmarks are to be used, describe in detail how these landmarks can consistently be identified, and agree on the method for taking body measurements on the human body.

According to Joseph-Armstrong (2010:23), there will never be a universally acceptable standard because of the variety of anatomical figure types. A standardised body scanning protocol should be developed for worldwide use (Honey \& Olds, 2007), because increasing world trade has created a need for a central database that contains regional measurements for non-Western trading partners (Joseph-Armstrong, $2010: 23)$. Revision of the definitions of the body measurements will assist in a more accurate and efficient updating of such a central database.

The Textile and apparel industry represents one of the two most dynamic sectors in global exports, with global apparel exports increasing by $138 \%$ during the last 14 years. With continuing increases in world population and global incomes, this industry is expected to grow by 5,3\% over the next decade (MultiFibre Arrangement Forum, 2008). This promises a potential market share for all efficient producers, including smaller and developing countries. Following the establishment of the Multi-Fibre Arrangement, it has been noticed that, although China's share of the cake got larger, the cake itself is now larger. Although there have been winners, there have unfortunately also been losers, with only nine of the 22 identified potentially vulnerable countries having succeeded in increasing their exports (Multi-Fibre Arrangement Forum, 2008). Two African countries, namely South Africa and Lesotho, are among those developing coun- tries (also included are South Korea, Mexico, Thailand and Romania) that have not succeeded in increasing their exports. The global apparel market therefore still remains a challenging environment for developing countries for pursuing responsible competitiveness.

As is most probably the case in many of these socalled loser countries, South Africa has decided to face the challenge of increasing its apparel export. Trade and Investment South Africa, a division of the Department of Trade and Industry, has decided to focus on promoting eight sectors of the South African economy that have shown the greatest growth potential and marketability, amongst which the Textile, Clothing and Leather and Footwear sector. Several leading international companies now have manufacturing facilities in South Africa, or have substantial procurement contracts with South African producers (South African Department of Trade and Industry; Textile, Clothing and Footwear Sector, 2009), while three major trade agreements are in effect, namely the Africa Growth and Opportunity Act, the South Africa/European Union (EU) Trade Development Agreement, and the Southern African Development Community (SADC) Free Trade Agreement. In addition, the Customised Sector Programme (CSP) was finalised in 2006 and is intended to develop and modernise the Clothing and Textile Industry for higher competitiveness. The industry therefore now has the opportunity to upgrade every level of its operations to become viable, to build strong relationships with the powerful retail sector, which also operates in many other African countries, and to increase its export trade.

\section{REFERENCES}

APEAGYEI, PR \& OTIENO, R. 2007. Usability of pattern customising technology in the achievement and testing of fit for mass customisation. Journal of Fashion Marketing and Management 11(3):349-365.

ASHDOWN, SP. 2002. Sizing systems. Available on line. URL: $\quad$ http://www.human.cornell.edu/txa/faculty/ SizingSystems. Accessed 2 June 2007.

ASHDOWN, SP. (Ed). 2007. Sizing in clothing: developing effective sizing systems for ready to wear clothing. Cambridge. Woodhead Publishing.

ASDOWN, SP \& DUNNE, L. 2006. A study of automated custom fit: readiness of the technology for the apparel industry. Clothing and Textiles Research Journal 24 (2):121-136.

BOUGOURD, J. 2007. Sizing systems, fit models, and target markets. In Ashdown, SP. 2007. Sizing in clothing: developing effective sizing systems for ready to wear clothing. Cambridge. Woodhead Publishing.

BYE, E \& LABAT, KL. 2005 An analysis of apparel industry fit sessions. Journal of Textile and Apparel, Technology and Management 4(3):1-5.

BYE, E, LABAT, KL \& DELONG, MR. 2006. Analysis of body measurement systems for apparel. Clothing and Textiles Research Journal 24(2):66-79.

CBNC Business. 2010. Available on line. URL: http:// www.cbncmagazine.com/story/Africa/1201/1/ Accessed 21 September 2010.

CHUN, J. 2007. Communication of sizing and fit. In Ashdown, SP. 2007. Sizing in clothing: Developing effective sizing systems for ready-to-wear clothing. Cambridge. Woodhead Publishing. 
CHUN-YOON, J \& JASPER, CR. 1993. Garment-sizing systems: an international comparison. International Journal of Clothing Science and Technology 5(5):28-37.

CHUN-YOON, J \& JASPER, CR. 1996. Key dimensions of women's ready-to-wear apparel: Developing a consumer size-labelling system. Clothing and Textiles Research Journal 14(1):89-95.

CLOTHNG FEDERATION OF SOUTH AFRICA HANDBOOK. 2000/1. The South African Clothing Industry. Bedfordview. Clothing Federation of South Africa.

CONNELL, LJ, ULRICH, PV, BRANNON, EL, ALEXANDER, M \& PRESLEY, AB. 2006. Body shape assessment scale: instrument development for analyzing female figures. Clothing and Textiles Research Journal 24(2):80-95. DA SILVA, I. 2010. Diamonds in the rough. Available on line. URL: http://wwwcbncmagazine.com/story/ africa/1201/1/ Accessed September 2010.

DUNNE, N. 2000. Understanding the South African clothing manufacturing sector from the perspective of leading South African clothing retailers. Research Report No 31. Industrial Restructuring Project. School of Developmental Studies. University of Natal. Durban.

FRINGS, GS. 1999. Fashion from concept to consumer. $6^{\text {th }}$ ed. Upper Saddle River, NJ. Prentice-Hall.

GIDDINGS, VL \& BOLES, JF. 1990. Comparison of the anthropometry of black males and white males with implications for pants fit. Clothing and Textiles Research Journal 8(3):25-28.

GOLDSBERRY, E, SHIM, S \& REICH, N. 1996. Women 55 years and older: Part II. Overall satisfaction and dissatisfaction with the fit of ready-to-wear. Clothing and Textiles Research Journal 14(2):121-132.

HONEY, F \& OLDS, T. 2007. The standards Australia sizing system: quantifying the mismatch. Journal of Fashion Marketing and Management. 11(3):320-331.

HUDSON, PB. 1980. The role of fit and fashion in apparel quality. Bobbin 21(11):108-122.

HWANG, S \& ISTOOK, CL. 2001. Body measurement terminology used in the

apparel industry. Paper presented at KSCT/ITAA Joint World Conference, 12-15 June 2001. Seoul, South Korea. JOSEPH-ARMSTRONG, H. 2010. Patternmaking for Fashion Design. $5^{\text {th }}$ ed. New York. Prentice-Hall.

KNIGHT, AL. 1994. The market feasibility of body scanning and size prediction technologies at retail. Unpublished Masters thesis. Greensboro. University of North Carolina. KUNICK, P. 1984 Modern sizing and pattern making for women's and children's garments. London. Philip Kunick.

LABAT, K \& DELONG, M. 1990. Body cathexis and satisfaction with fit of apparel. Clothing and Textiles Research Journal 8(2):43-47.

Le PECHOUX, B \& GHOSH, TK. 2002. Standard sizing and fit testing applied to women's hosiery. Textile Progress. 32(1):1-39.

LOKER, S, ASHDOWN, S \& SCHOENFELDER, K. 2005. Size-specific analysis of body scan data to improve apparel fit. Journal of Textile and Apparel, Technology and Management (4)3:1-15.

MYERS-McDEVITT, PJ. 2009. Complete guide to size specification and technical design. New York. Fairchild Books.

MULTI-FIBRE ARRANGEMENT FORUM. 2008. Global apparel trade trends briefing. Multi-Fibre Arrangement Forum Convening. New York.

NEDSCAN BODY MEASURES. Available on line. URL: http://www.nedscan.nl/nedscan/maatuk.html. Accessed on 11 July 2001.

NEUMAN, WL. 2000. Social research methods. Qualitative and quantitative approaches. $4^{\text {th }}$ ed. London. Allyn \& Ba- con.

NEWCOMB, B \& ISTOOK, C. 2004. A case for the revision of U.S sizing standards. Journal of Textile and Apparel Technology and Management 4(1):1-6.

ODHIAMBO, T. 2008. The black female body as a 'consumer and a consumable' in current Drum and True Love magazines in South Africa. African Studies. 67(1):7180.

PETROVA, A. 2007. Creating sizing systems. In Ashdown, SP. (Ed). 2007. Sizing in clothing: developing effective sizing systems for ready to wear clothing. Cambridge. Woodhead Publishing.

ROBERTS, DF. 1972. Population differences in dimensions, their genetic basis and their relevance to practical problems of design. In Chapanis, A. (Ed). 1972. Ethnic variables in human factors engineering. Baltimore. The John Hopkins University Press.

SHIM, SH \& ISTOOK, CL. 2007. The importance of understanding the shape of diverse ethnic female consumers for developing jeans sizing systems. International Journal of Consumer Studies 31:135-143.

SHOES AND VIEWS DIRECTORY. 2001. S\&V. The complete shoe, leather and fashion accessories trade magazine for Southern and Eastern Africa 64(5):17-47.

SIMMONS, KL \& ISTOOK, CL. 2003. Body measurement techniques. Comparing 3D body-scanning and anthropometric methods for apparel applications. Journal of Fashion Marketing and Management 7(3):306-332.

SIMPSON, J. \& DORE, B. 2007. Marketing in South Africa. Cases and concepts. Cape Town. Van Schaik.

SizeUK. 2000. 3D scanner technology survey and proofing. Centre for 3D Electronic commerce. London.University College of London.

SMIT, T. 1997. Quality assurance in the South African clothing industry. Journal of Dietetics and Home Economics 25(1):64-67.

STRYDOM, M. 2006. An evaluation of South African clothing related population measures and sizing systems. MConsSc dissertation. Pretoria. University of Pretoria. Available on line. URL: http://upetd.up.ac.za/thesis/ available/etc-08122008-110341/

SOUTH AFRICAN DEPARTMENT OF TRADE AND INDUSTRY. Textile, Clothing and Footwear Sector. Available on line. URL: http://www.thedti.gov.za/publications/ textiles.htm. Accessed on 10 October 2009.

TAMBURINO, N. 1992. Apparel sizing issues, part 2. Bobbin 33(9):52-60.

THE CLOTHING FEDERATION OF SOUTH AFRCIA HANDBOOK. (2000/1). The South African Clothing Industry. Bedfordview. Clothing Federation of South Africa.

WINKS, JM. 1990. The development of standard sizing systems for clothes. MSc thesis. Port Elizabeth. University of Port Elizabeth.

WINKS, JM. 1997. Clothing sizes. International standardization. Manchester. Redwood Books.

YU, W. 2004. Subjective assessment of clothing fit. IN Fan, J, Yu, W \& Hunter, L. 2004. Clothing appearance and fit: science and technology. Cambridge. Woodhead Publishing.

ZWANE, PE \& MAGAGULA, N. 2007. Pattern design for women with disproportionate figures: a case study for Swaziland. International Journal of Consumer Studies 31:283-287.

ZWANE, PE, SITHOLE, M \& HUNTER, L. 2010. A preliminary comparative analysis of 3D body scanner, manually taken girth body measurements and size chart measurements. International Journal of Consumer Studies. 34:265271. 